\title{
Mudanças no controle da leishmaniose visceral no Brasil
}

\author{
Changes in the control program of visceral leishmaniasis in Brazil
}

Depois de duas décadas de tentativas de controle da leishmaniose visceral (LV) no Brasil, o número de casos no país aumentou nitidamente e invadiu áreas urbanas, onde encontrou-se com a AIDS ${ }^{27}$. A recente proposta do Ministério da Saúde de reavaliar os programas de controle de endemias, aliada ao reconhecimento da pouca eficiência do programa brasileiro para LV, levou à convocação de um comitê de consultores para analisar o programa atual e propor mudanças para o controle da doença no país. Foram realizadas algumas reuniões do grupo técnico, a última tendo ocorrido em 4 de dezembro de 2000 em Brasília. Esta reunião contou com a presença dos consultores da Ministerio da Saúde e Técnico da Fundação Nacional de Saúde: Almério de Castro Gomes (Universidade de São Paulo), Carlos Henrique Nery Costa ( Universidade Federal do Piauí), Jackson Mauricio Lopes Costa (Universidade Federal do Maranhão), João Batista Furtado Vieira (Fundação Nacional de Saúde), José Wellington de Oliveira Lima (Fundação Nacional de Saúde) e Reinaldo Dietze (Universidade Federal do Espírito Santo). Em fevereiro de 2001, as modificações propostas foram apresentadas para os representantes das secretarias estaduais de saúde e das coordenações regionais da Fundação Nacional de Saúde, para implementação.

O programa brasileiro, iniciado há mais de 40 anos, é composto pela integração de três medidas de saúde pública: a distribuição gratuita do tratamento específico, o controle de reservatórios domésticos e o controle de vetores. A medicação distribuída nas unidades públicas de saúde onde se trata LV são compostos de antimônio pentavalente, com dose recomendada de $20 \mathrm{mg} / \mathrm{kg} /$ dia por no mínimo 20 dias. O controle de reservatórios tem sido feito através do diagnóstico sorológico de todos os cães domésticos onde existe transmissão de Leishmania chagasi para seres humanos. Para isto, foi estruturada uma rede de testes de imunofluorescência, utilizando-se eluato de papel de filtro; todos os cães com resultado reagente têm sido sacrificados. Finalmente, o controle do vetor, essencialmente para o flebótomo Lutzomyia longipalpis, é aplicado eventualmente com o uso de inseticidas, por
After two decades of efforts to control visceral leishmaniasis (VL) in Brazil, the nation's number of cases have had a distinct increase, and invaded cities where VL met AIDS ${ }^{27}$. The recent proposition of the Ministry of Health to evaluate the programs of control of endemic diseases and the recognition of the poor performance of the Brazilian program for VL, led to the calling of a committee of advisers. They were asked to analyze the present program and to suggest changes for the control of the disease in the country. Some meetings took place in the year 2,000 , the last in the $4^{\text {th }}$ of December. The following advisers attended this last meeting: the Counselor of the Ministerio da Saúde e Technician of the Fundação Nacional de Saeude: Almério de Castro Gomes (Universidade de São Paulo), Carlos Henrique Nery Costa ( Universidade Federal do Piauí), Jackson Mauricio Lopes Costa (Universidade Federal do Maranhão), João Batista Furtado Vieira (Fundação Nacional de Saúde), José Wellington de Oliveira Lima (Fundação Nacional de Saúde) e Reinaldo Dietze (Universidade Federal do Espírito Santo). In February of 2001, the proposed changes were presented to the regional offices of Fundação Nacional de Saúde and to the state health offices, for implementation.

The Brazilian program started more than 40 years ago. Free delivery of specific drug therapy, the control of the domestic reservoir and vector control are its three integrated components. Pentavalent antimony is the medication freely delivered at the public health units where VL is treated, at the dose of $20 \mathrm{mg} / \mathrm{kg} / \mathrm{day}$ for at least 20 days. Reservoir control has been performed by serological testing of all domestic dogs where transmission of Leishmania chagasi to humans exists. In order to achieve this goal a network of immunofluorescence tests using eluate from filter paper has been established; all dogs with a reagent result have been culled. Finally, vector control, essentially for the Lutzomyia longipalpis, has been eventually applied by the use of insecticides, either by environmental spraying (mostly) or by residual application 2229 .

Endereço para correspondência: Dr. Carlos Henrique Nery Costa. Laboratório de Leishmanioses/Hospital de Doenças Infecto-Contagiosas. R. Gov. Artur de Vasconcelos 151-Sul, 64000-450 Teresina, PI, Brasil.

Tel: 5586 221-3413 Fax: 5586 221-2424

e-mail: crlshncst@aol.com

Recebido em 23/2/2001 
aspersão espacial (principalmente) ou por aplicação residual 2229

A recente epidemia devastadora do Sudão, onde populações deslocadas pela guerra civil tinham pouco acesso à medicação para $\mathrm{LV}^{31}$, deixou claro que a ampla distribuição gratuita do tratamento específico é crucial para a prevenção da morte, particularmente entre os mais pobres, contingente que constitui a maioria das vítimas de LV.

Salvo pequenas modificações, decorrentes de análises e experiências recentes, as recomendações anteriores para o tratamento específico foram ratificadas pelo comitê de consultores. Baseado em revisão dos esquemas utilizados até o presente, sugeriu-se passar a duração mínima de 20 dias para 30 dias $^{6}$. A excreção quase totalmente renal do antimônio pentavalente ${ }^{821}$ e ausência de tabela para uso em pacientes com insuficiência renal, a conhecida eliminação extra-renal da anfotericina $\mathrm{B}^{12}$ e o fato de seus níveis séricos não serem afetados na insuficiência renal ${ }^{5}$ (e apesar de sua nefrotoxicidade) levaram à indicação do uso, ainda que cauteloso, de anfotericina B como droga de escolha para pacientes com LV em insuficiência renal. A segurança do uso de anfotericina B na gestação ${ }^{33}{ }^{34}$ e a falta de estudos conclusivos sobre a teratogenicidade de antimônio ${ }^{23}$, levaram à recomendação de indicação de anfotericina B na gestação. Foram consideradas medidas de segurança a dosagem de creatinina do soro antes do início do tratamento e o acompanhamento eletrocardiográfico de pessoas mais velhas ou com cardiopatias.

O programa de eliminação de cães domésticos apresenta o menor suporte técnico-científico entre as 3 estratégias do programa de controle. Foram identificados 10 pontos de maior fragilidade: 1) A falta de correlação espacial entre a incidência cumulativa de LV humana com a soroprevalência canina ${ }^{26}$. 2) A ausência de risco significativo de coabitação com cães para aquisição de LV ${ }^{10}$. 3) A demonstração teórica de que é um método pouco eficiente em comparação com as estratégias de controle vetorial e de suplementação alimentar ${ }^{15}{ }^{30}$. 4) A demonstração de que outros reservatórios podem ser fontes de infecção de $L$. chagasi, tais como pessoas (particularmente crianças desnutridas que podem transmitir para outras crianças) ${ }^{11}$, canídeos silvestres ${ }^{13}$ e marsupiais $^{32}$. 5) A grande velocidade com que a população canina é reposta, exigindo proporção e freqüência de retiradas de cães soropositivos impraticáveis ${ }^{7}$. 6) A baixa eficiência dos testes sorológicos em detectar infecção canina ${ }^{16}$. 7) A utilização de um único método para efetuar as duas funções de teste de triagem e de teste confirmatório para infecção por L. chagasi; isto conduz a elevado custo por benefício devido à alta proporção de resultados falso-positivos, particularmente quando a prevalência real é baixa ${ }^{1835}$. 8) A falta de indicadores clínicos ou laboratoriais de infectividade de cães para o vetor ${ }^{28}$. 9)
The recent devastating VL epidemic in Sudan where displaced populations had little access to the medication ${ }^{31}$, clearly certified that extensive free delivery of specific therapy is crucial for the prevention of death, particularly among the poorest, the group that comprises the majority of victims of VL.

Except for little changes and due to recent reviews and experiences, the committee ratified the previous recommendations for specific therapy. Based on a recent review on the schemes previously used the minimal duration was suggested to be changed from 20 days to 30 days $^{6}$. The almost complete renal excretion of pentavalent antimony $^{821}$, and the absence of guidelines for use in patients with renal failure, the well known extrarenal degradation of amphotericin $\mathrm{B}^{12}$ and the fact that its serum levels are not affected in renal failure ${ }^{5}$ (and regardless its nephrotoxicity) led to indication, yet with caution, of amphotericin B as the drug of choice for patients with VL and renal failure. The safety of the use of amphotericin B in pregnancy ${ }^{33} 34$ and the lack of conclusive studies on the teratogenicity of antimony ${ }^{23}$ led to the recommendation for indicating amphotericin $B$ in pregnancy. The dosage of serum creatinine before beginning drug therapy and the electrocardiographic follow-up of older persons and of patients with cardiopathy were considered security procedures.

The domestic dogs culling program presents the least scientific and technical support among the three components of the control program. Ten very fragile points were identified: 1) The lack of spatial correlation between the cumulative incidence of human VL and dog seroprevalence ${ }^{26}$. 2) The absence of meaningful risk in living with dogs for the occurrence of $\mathrm{VL}^{10}$. 3) The theoretical demonstration that this is a method with little efficiency as compared to the strategies of vector control and food supply ${ }^{15}{ }^{30}$. 4) The demonstration that other reservoirs may be additional sources of infection of $L$. chagasi, like persons (particularly malnourished children who may infect other children) ${ }^{11}$, sylvatic canines ${ }^{13}$ and opossums ${ }^{32}$. 5) The high speed in which the dog population is replaced; this dynamics demands nonrealistic, proportion and frequency, of seropositive dog removing ${ }^{7} .6$ ) The low efficiency of serologic tests to detect dog infection ${ }^{16}$. 7) The use of only one method to perform the two functions of a screening test and confirmatory test; this leads to a high cost per benefit due to the high proportion of falsepositive final results, particularly when the real prevalence is $\operatorname{low}^{1835}$.8) The lack of clinical or laboratory predictors of canine infectivity to the vector $^{28}$. 9) The absence of previous experiences demonstrating unequivocal advantage of dog 
A ausência de experiências anteriores que tenham demonstrado vantagens exclusivas da eliminação de cães, pois todos os relatos de sucesso de programas de controle de LV onde foram eliminados cães descrevem também o controle de vetores com inseticidas $^{12425}$. 10) A publicação de observações e ensaios em que se verificou que quando esta medida foi aplicada sozinha, não houve demonstração inequívoca da vantagem de seu uso em reduzir a incidência de LV em seres humanos ${ }^{314} 17$.

Os consultores recomendaram então que a triagem sorológica universal sistemática de todos os cães seguida de eliminação deve ser suspensa. Sugeriram que, na ausência do vetor ou de casos humanos, as únicas medidas para as áreas com leishmaniose visceral canina devem ser de vigilância e de educação em saúde. Devem ser promovidos inquéritos sorológicos amostrais contingenciais de infecção canina e a intensificação da identificação de vetores. Indicaram a necessidade de formulação de programa de educação sobre a doença para o pessoal de saúde no sentido de alertar para o diagnóstico em seres humanos, e outro programa educativo, voltado para médicos-veterinários, com a recomendação de não tratarem cães doentes com as drogas disponíveis, tanto pela ineficiência como medida de saúde pública devido à infectividade para flebótomos de cães tratados como pelo risco de desenvolvimento de resistência à medicação a longo prazo ${ }^{2}$. Foi recomendado também que a população seja alertada para solicitar às unidades de controle de zoonoses o exame de seus cães com sintomatologia suspeita. Foi indicado que o teste sorológico de eluato de sangue em papel de filtro deva ser substituído por sorologia convencional. O comitê acha que a eliminação de cães deve ser restrita apenas para as situações em que o diagnóstico de leishmaniose visceral for confirmado parasitologicamente ou que exames sorológicos confirmem casos clinicamente suspeitos, em cães procedentes de áreas endêmicas.

Fundamentado em numerosos relatos e ensaios de bons resultados no controle de LV onde houve aplicação de inseticidas para o controle de LV, antroponótico ou não, ou de outras doenças transmitidas por vetores, tais como malária e doença de Chagas ${ }^{19} 19$ 20, os consultores enfatizaram que a prioridade do programa de controle da transmissão deve ser dada para o controle de vetores, em vez da atual ênfase conferida ao controle de reservatórios. $O$ comitê sugeriu a distinção entre as circunstâncias em que o uso de inseticidas está formalmente indicado das situações em que medidas mais conservadoras devem ser tomadas. Recomendou que a aplicação de inseticidas só pode ser efetivada quando houver registro de casos humanos na área. Mesmo na presença de casos humanos, o comitê só recomendou o controle de vetores para as áreas onde pelo uma das três seguintes situações estiver presente em uma área culling; all reports of success of VL control programs where dogs had been tested also describe concurrent vector control with insecticides ${ }^{12425}$. 10) The report of observations and trials showing that when dog culling was the only strategy applied no unequivocal benefits for reducing human VL were observed 31417 .

Therefore the advisers recommended that the systematic universal serological screening of all dogs followed by elimination should be discontinued. They suggested that in the absence of the vector or of human disease the only measures to be taken in areas where dog infection exists are vigilance and health education. Contingent limited serological surveys for dog infection and the intensification of vector identification should be accomplished. The advisers also pointed the necessity of formulation of health education programs for health professionals aiming the detection of human disease and also for veterinarians with the purpose of not treating sick dogs. The last measure is based on the lack of public health efficiency of the available drugs because treated dogs remain infective to sand flies and on the risk of development of drug resistance ${ }^{2}$. They recommended that the population should be alerted to ask to the units for the control of zoonosis the examination of their symptomatically suspected dogs. The substitution of serology with eluate from blood in filter papers by conventional serology was suggested. The committee recommends that the elimination of dogs should be restricted to parasitologically confirmed cases or to situations in which serology confirms the clinical diagnosis in dogs from in endemic areas.

Based on several descriptions and trials with good results on the control of $V L$ in areas where the insecticides were applied for control zoonotic or anthroponotic VL, or for the control of other vector-borne diseases like malaria and Chagas disease ${ }^{1920}$, the advisers stressed that the priority for the control of transmission should be given to vector control, instead of the present emphasis on reservoir control. The committee suggested a distinction between the circumstances where the use of insecticides is formally indicated and the situations where more conservative measures should be undertaken. The use of insecticides is recommended only when human disease occurs. Even in the presence of human cases the committee recommended vector control in limited areas, only when at least one of the three followings situations is present: 1) Recent introduction of the disease. 2) Clear increase in the incidence. 3) Cumulative incidence higher than 5 cases per 100,000 per year. When none of these characteristics is present the committee recommended only the intensification of 
limitada: 1) Introdução recente da doença. 2) Aumento nítido da incidência. 3) Incidência cumulativa maior que 5 casos por 100.000 habitantes por ano. Quando nenhuma das características acima estiver presente, o comitê recomendou que apenas se intensifique a tentativa de identificação de casos humanos adicionais na área (buscando justificativa adicional para uso eventual de inseticidas), o treinamento de profissionais de saúde para assegurar o reconhecimento da doença e a ampliação da procura do vetor para as áreas vizinhas. Ressaltou que a aplicação de inseticidas deve-se restringir a aplicações residuais, com cobertura extensiva de todo o domicílio e seus anexos.

O comitê enfatizou os resultados de um estudo de coorte que havia identificado um maior risco de crianças desnutridas infectadas por $L$. chagasi desenvolverem os sintomas de LV4. Mesmo ciente que esta associação não foi confirmada em dois outros estudos de coorte ${ }^{16} 29$, (talvez decorrente de erro tipo $\mathrm{II}^{16}$, ou da carência de algum nutriente de efeito ainda desconhecido na LV, ausente em uma área mas presente nas outras) classificou o fator de risco como relevante e passível de intervenção. Por isto, recomendou que o programa de controle de leishmaniose visceral se articule com os programas de assistência nutricional, a fim de priorizar suplementação alimentar às crianças de alto risco de infecção por L. chagasi.

O comitê de assessores reconheceu que muitos pontos da epidemiologia e profilaxia da LV não estão ainda devidamente esclarecidos, o que dificultou a escolha das melhores recomendações. Por isto, sugere que o Ministério da Saúde e agências oficiais de fomento à pesquisa devam encomendar pesquisas à comunidade científica sobre a epidemiologia e o controle da LV. Chama especial atenção para tópicos relevantes tais como: quais são de fato as principais fontes de $L$. chagasi para populações humanas; testes diagnósticos que identifiquem a infectividade de cães para Lu. longipalpis; e a análise de estratégias para o uso de inseticidas mais efetivas e menos danosas.

O comitê entende que existem recomendações com alguma imprecisão mas acredita que possam ser mais adequadamente especificadas através de decisões tomadas localmente, de acordo com as peculiaridades regionais. Finalmente, o comitê acredita que as modificações propostas resultarão em aplicação mais racional e eficiente dos recursos destinados ao controle desta endemia. the investigation of the presence of more human disease (aiming the epidemiologic justification for eventual use of insecticides), the training of health professionals to assure the detection of the disease and the amplification of the search for vectors to neighbor areas. The advisers stressed also that the application of insecticides should be restricted to residual applications, and that they should be employed extensively in the entire domicile and its annexes.

The committee emphasized the results of one cohort study that shows that malnourished children infected with $L$. chagasi are at a higher risk of developing the symptoms of $\mathrm{VL}^{4}$. Nevertheless noticing that this association has not been confirmed in two other cohort studies ${ }^{1629}$ (perhaps due to type II error ${ }^{16}$, or to the lack of nutrients with yet unknown action on $\mathrm{VL}$, absent in the former area but present in the others) the committee classified the risk factor as meaningful and as a target for intervention. Therefore, the consultants recommended an interplay among the program of control of visceral leishmaniasis and the programs for nutritional assistance, in order to give preference for food supplementation to children at high risk of being infected by $L$. chagasi.

The committee of advisers acknowledged that several points in the epidemiology and prevention of VL are not sufficiently clarified, making it difficult the choice of the best recommendations. Accordingly, the advisers recommended that the Ministry of Health and official research financing agencies should call for research applications on the epidemiology and control of VL. They highlighted relevant topics such as the elucidation of the actual sources of $L$. chagasi for humans, the search for tests for the identification of dog infectivity to Lu. longipalpis and the analysis of the most effective and least harmful insecticide application strategies.

The committee realizes that some recommendations lack some precision but believes that decisions taken locally, accordingly to regional peculiarities, may be more adequately specified. Finally the committee believes that these proposed changes will result in a more rational and efficient application of the resources destined to the control of this disease.

\section{REFERÊNCIAS BIBLIOGRÁFICAS}

1. Alencar JE. Profilaxia do calazar no Ceará, Brasil. Revista do Instituto de Medicina Tropical de São Paulo 3: 175-180, 1961.

2. Alvar J, Molina R, Andrés MS, Tesouro M, Nieto J, Vitutia M, González F, Andrés MDS, Boggio J, Rodriguez F, Sáinz A, Escacena C. Canine leishmaniasis: clinical, parasitological and entomological follow-up after chemotherapy. Annals of Tropical Medicine and Parasitology 88: 371-378, 1994..
3. Ashford DA, David JR, Freire M, David R, Sherlock I, Eulálio MC, Sampaio DP, Badaro R. Studies on control of visceral leishmaniasis: impact of dog control on canine and human visceral leishmaniasis in Jacobina, Bahia, Brazil. The American Journal of Tropical Medicine and Hygiene 59: 53-57, 1998.

4. Badaró R, Jones TC, Lorenço R, Cerf BJ, Sampaio D, Carvalho EM, Rocha H, Teixeira R, Johnson Jr WD. 
A prospective study of visceral leishmaniasis in an endemic area of Brazil. Journal of Infectious Diseases 154: 639-649, 1985.

5. Bennett JE. Antifungal agents. In: Mandell GL, Bennett JE, Dolin R (ed) Principles and practice of infectious diseases, Churchill Livingstone, New York, 1995.

6. Berman JD. Human leishmaniasis: clinical, diagnostic, and chemotherapeutic developments in the last 10 year. Clinical Infectious Diseases 24: 684-703, 1997.

7. Braga MDM, Coelho ICB, Pompeu MML, Evans TG, MacAuliffe IT, Teixeira MJ, Lima JWO. Controle do calazar canino: comparação dos resultados de um programa de eliminação rápida de cães sororreagentes por ensaio imuno-enzimático com outro de eliminação tardia de cães sororreagentes por teste de imunofluorescência indireta de eluato de papel de filtro. Revista da Sociedade Brasileira de Medicina Tropica 31: 419-510, 1998.

8. Bryceson, A. Therapy in man. In: Peters W, Killick-Kendrick $R$ (eds) The leishmaniasis in biology and medicine, Academic Press, London, p. 848-907, 1987.

9. Costa CHN, Pereira HF, Araujo MV. Epidemia de leishmaniose visceral no Estado do Piauí, Brasil (1980-1986). Revista de Saúde Pública 24: 361-372, 1990

10. Costa CHN, Pereira HF, Pereira FC, Tavares JP, Araújo MV, Gonçalves MJO. Is the household dog a risk factor for American visceral leishmaniasis? Transactions of the Royal Society of Tropical Medicine and Hygiene 93: 464, 1999

11. Costa CHN, Gomes RBB, Gonçalves MJO, Garcez LM, Ramos PKS, Santos RS, Shaw JJ, David JR, Maguire JH. Competence of human host as reservoir for Leishmania chagasi. Journal of Infectious Diseases 182: 997-1000, 2000.

12. Craven PC, Ludden TM, Drutz DJ, Rogers W, Haegele KA, Skrdlant HB. Excretion pathways of amphotericin B. Journal of Infectious Diseases 140: 329-341, 1979.

13. Deane LM. Reservatórios de Leishmania donovani no Brasil. Revista do Instituto de Medicina Tropical de São Paulo 4: 198212, 1962

14. Dietze R, Barros GB, Teixeira L, Harris J, Michelson K, Falqueto A, Corey R. Effect of eliminating seropositive canines on the transmission of visceral leishmaniasis in Brazil. Clinical Infectious Diseases 25: 1240-1242, 1999.

15. Dye $\mathrm{C}$. The logic of visceral leishmaniasis control. The American Journal of Tropical Medicine and Hygiene 55: 125130, 1996.

16. Dye C, Vidor E, Dereure J. Serological diagnosis of leishmaniasis: on detecting infection as well as disease. Epidemiology and Infection 103: 647-656, 1993.

17. Evans TG, Teixeira MJ, McAuliffe IT, Vasconcelos IAB, Vasconcelos AW, Sousa AQ, Lima JWO, Pearson RD. Epidemiology of visceral leishmaniasis in Northeast Brazil. Journal of Infectious Diseases 166:1124-1132, 1992.

18. Gart J, Buck AA. Comparison of a screening test and a reference test in epidemiological studies. II. A probabilistic model for the comparison of diagnostic methods. American Journal of Epidemiology 83: 593-602, 1966.

19. Guan LR. Current status of kala-azar and vector control in China. Bulletin of the World Health Organization 69: 595-601, 1991.

20. Gupta S. Return of kala-azar. Journal of Indian Medical Association 65: 89-90, 1975.

21. Hantson P, Luyasu S, Haufroid V, Lambert M. Antimony excretion in a patient with renal impairment during meglumine antimoniate therapy. Pharmacotherapy 20: 1141-1143, 2000.

22. Lacerda, M. The Brazilian leishmaniasis control program. Memórias do Instituto Oswaldo Cruz 89: 489-495, 1994.

23. Leonard A, Gerber GB. Mutagenicity, carcinogenicity and teratogenicity of antimony compounds. Mutation Research 366:1-8, 1996.

24. Lu CC, Chung HL, Ling CC, Wu CC, Wang CC, Chiang YT, Hsü WF. New China's achievements in the kala-azar treatment and prevention of kala-azar. Chinese Medical Journal 78: 9199, 1955.

25. Magalhães PA, Mayrink W, Costa CA, Melo MN, Dias M, Batista SM, Michalick MSM, Williams P. Calazar na Zona do Rio Doce - Minas Gerais. Resultados de medidas profiláticas. Revista do Instituto de Medicina Tropical de São Paulo 22: 197-202, 1980.

26. Maguire JH, Costa $\mathrm{CH}$, Lamounier D, Beck LR, Lobitz B, Dister D, Wood B. Remote sensing and geographic information systems technology applied to infectious disease transmission of Leishmania chagasi in Teresina, Piaui, Brazil. In: Sixth Annual Meeting NIAID International Centers for Tropical Disease Research, US Department of Health and Human Services, National Institutes of Health, 1997.

27. Ministério da Saúde. Controle, Diagnóstico e tratamento da leishmaniose visceral. Fundação Nacional de Saúde, Brasília, 1999.

28. Molina R, Amela C, Nieto J, San Andrés M, Gonzalez F, Castillo JA, Lucientes J, Alvar J. infectivity of dogs naturally infected with Leishmania infantum to colonized Phlebotomus perniciosus. Transactions of the Royal Society of Tropical Medicine and Hygiene 88: 491-493, 1994.

29. Monteiro P, Lacerda MM, Arias JR. Controle da leishmaniose visceral no Brasil. Revista da Sociedade Brasileira de Medicina Tropical 27 (supl III): 67-72, 1994.

30. Nascimento MRSB. Epidemiologia da leishmaniose visceral na Ilha de São Luís, Maranhão - Brasil: análise da dinâmica de transmissão e dos fatores de risco relacionados ao desenvolvimento da doença. Tese de Doutorado. Escola Paulista de Medicina, São Paulo, SP, 1996.

31. Seaman J, Mercer AJ, Sondorp E. The epidemic of visceral leishmaniasis in Western Upper Nile, Southern Sudan: course and impact from 1984 to 1994. International Journal od Epidemiology 25: 862-871, 1996.

32. Sherlock IA, Miranda JC, Sadigursky M, Grimaldi G. Natural infection of the opossum Didelphis marsupialis (Marsupialia Didelphidae) with Leishmania chagasi in Brazil. Memórias do Instituto Oswaldo Cruz 79: 511, 1984. 
33. Sobel JD. Use of antifungal drugs in pregnancy: a focus on safety. Drug Safety 23: 77-85, 2000.

34. Thakur CP, Singh RK, Hassan SM, Kumar R, Narain S, Kumar A. Amphotericin deoxycholate treatment of visceral leishmaniasis with newer modes of administration and precautions: a study of 938 cases. Transactions of the Royal Society of Tropical Medicine and Hygiene 93: 319-323, 1999.

35. Weinstein MC, Fineberg HV, Elstein AS, Frazier HS, Neuhauser D, Neutra RR, McNeil BJ. Clinical decision analysis. Saunders, Philadelphia, 1980.

\section{Carlos Henrique Nery Costa $^{1}$ e João Batista Furtado Vieira ${ }^{2}$}

